\title{
Influence of using some natural materials and biological fertilizers on growth and quality of pea yield
}

\author{
Usrya A. I. Byan and Nahed M.M. EL-Shimi \\ Veg. Res. Dep., Hort. Res. Inst., Agric. Res. Center, Giza, Egypt
}

\begin{abstract}
Two field experiments were carried out during winter season of 2011 and 2012 years at the Experimental Farm of Kaha Station, Qalubia Governorate to study the influence of with some natural stimulants on pea plants c.v Master B using ascobean compound as a source for citric and ascorbic acids as well as power-mix compound as a source for amino acids and using also two natural fertilizers, i.e. rock phosphate as a source of phosphours + feldspar as a source of potassium by soil application during soil preparation, In addition,treating pea seeds before sowing with four biological materials, i.e. phosphoren, potassiumag, rhizobium and mycorrhizal comparing with the normal fertilizer recommendation as control . It was found that adding rock phosphate + feldspar +rhizobium+ mycorrhizal and the treatment of rock phosphate + feldspar +rhizobium+ potassiumag +phosphoren respectively, were the favorable treatments on induce significant results on growth, i.e. plant height, number of leaves/ plant, fresh and dry weight/plant. The same treatments led to significant values on pod characters, i.e., pod weight, number of seeds/pod, weight of 100 seed and total green pods yield. Moreover the treatment of adding rock phosphate + feldspar + rhizobium + mycorrhizal induced significant increases in nitrogen concentration as well as protein content in the seeds, while the favorable treatment on increasing seed sugar content was treating the seeds with rhizobium and mycorrhizal. It was found also that adding rock phosphate +feldspar +mycorrhizal led to high phosphorus concentration in pea seeds. The treatment of foliar spray with ascobean induced significant increases in nitrogen, phosphorus and protein seed contents as well as leaf content from chlorophyll. The sugar concentration in pea seeds increased significantly by powermix application.

Generally it can be recommended by adding rock phosphate as natural source of phosphorus +feldspar as a source of natural potassium and treating pea seeds with rhizobium ,phosphorien, potassumag as a biological material and spray pea plants with ascobean or power - mix without adding any chemical fertilizers to produce high green pod yield with favorable quality comparing with the normal fertilizer recommendation.
\end{abstract}

Key words: pea - foliar nutrition - amino acids - biological materials - feldspar - rock phosphate.

\section{Introduction}

Pea (Pisum sativum L.) is one of the major leguminous crops either as green pod yield or dry seed yield in winter growing season in Egypt. Increasing the production of the green pods and dry seeds with high quality is considering an important aim. Also the reduction of chemical fertilizers arises as a factor of health care. Hence, attempts done for solving problems of chemical fertilization using biofertilizers beside addition of low amounts of chemical fertilizer has been reported to be one of the main factors to encourage the growth vigor as well as peas yield and its chemical composition.

Fertilizers being vital agriculture input to the increase in the population but the main drawbacks by the use and manufacture of chemical viz., energy crisis and unavailability of indigenous effects of chemical fertilizers on our health and environment. All these things have led to the search of alternative renewable source of nutrient for the crop through fertilizers of biological origin (biofertilizers). The bio-fertilizers are safe, low cost and easy in application. Bio-fertilizer application have shown good results in case of leguminous (pulse) crop, especially exclusive results have been obtained in case of vegetable pea (garden pea).

Most plant species exploit the soil with the help of beneficial microorganisms called mycorrhizal fungi. Mycorrhiza offers several benefits to the host plant, including faster growth, improved nutrition and improved soil structure. Arbuscular mycorrhiza (AM) acts as a major conduit in principal elemental cycles (Fitter et al. 2011). It can increase plant nutrient uptake and growth (Cameron 2010). Mycorrhiza may especially enhance plant uptake of phosphors $(\mathrm{P})$, nitrogen $(\mathrm{N})$ and micro nutrients (Marschner and Dell 1994).

Rhizobium sp. is the symbiotic nitrogen fixer which assimilates atmospheric nitrogen and fixes in the root nodule, formed in the roots of leguminous plants. These bacteria infect the roots of leguminous plants, leading to the formation of "lumps" or "nodules", where the nitrogen fixation takes place. The bacterium also produces enzymes (nitrogenase) that supply a constant source of reduced nitrogen to the host plant. Geneva et al (2006) studied the response of pea (Pisum sativum cv. Avola) to arbuscular mycorrhizal fungi (AM) species Glomus mosseae and Glomus intraradices and Rhizobium 
leguminosarum bv. viceae, strain D 293, regarding the growth, photosynthesis, nodulation and nitrogen fixation activity. The obtained results demonstrated that the dual inoculation of pea plants significantly increased the plant biomass, photosynthetic rate, nodulation, and nitrogen fixation activity in comparison with single inoculation with Rhizobium leguminosarum bv. Viceae. Inoculation with Rhizobium increased the seed yield and its components of faba bean in six areas in Australian (Carter et al., 1994). The use of rhizobium inoculants enhances environmental safety (Neeraj $\boldsymbol{e t}$ al., 2009). Moreover, Rabbani et al. (2005), Jonah et al (2012) reported that rizobium inoculation improved growth, chemical composition, yield and its quality of leguminous vegetable crops.

Reading with the importance of adding dissolving phosphobacteria which is one of the major bio fertilizers especially under the Egyption soil. phosphorus is a major nutrient for plants inducing vigorous growth and also contributing to their disease resistance. Phosphorous helps in root formation and plant growth. The plants utilize only $10-15 \%$ of the applied phosphate, and the residual 85 $-90 \%$ remains in insoluble form in the soil. The bio promoters have highly efficient phosphate solubilizing bacteria (Bacillus megaterium) that grow and secrete organic acids, which dissolve this unavailable phosphate into soluble form and make it available to the plants. Thus, the residual phosphate fertilizers in the soil can be well utilized and external application can be optimized. Ganie et al. (2010) worked on pea indicated that the co- inoculation of Rhizobium, Azotobacter and phosphorus solubilising microorganism (PSM) produced noticeably highest growth in terms of plant height, no of leaves and branches and also highest yield in the tune of maximum pod length, number of pods plant-1, number of seeds pod-1 and yield of pods. Mahdi $\boldsymbol{e t}$ al. (2011) reported that, use of phosphate solubilizing microorganisms play vital role in solubilizing the insoluble forms of phosphorus. Strains from genera Pseudomonas, Bacillus, Rhizobium, Aspergillus and Cephalosporium increases crop yield.

Soil forms from rock in the first place; poor soil can be improved by adding specific types of rock dust chosen for their mineral content. The volcanic basalt, granite, dolomite rock phosphate and rock potash, slowly release a complete spectrum of minerals and trace elements which provides the perfect environment for natural farming. Since, rock in the long term improvement of their soil structure and increased crops productivity without negative effects on the environment. For example; Feldspar comprises a group of minerals containing potassium, sodium, calcium and aluminium silicates. The common feldspar is potassium feldspar, namely, orthoclase $\left(\mathrm{K}_{2} \mathrm{O}, \mathrm{Al}_{2} \mathrm{O}_{3}, 6 \mathrm{SiO}_{2}\right)$. Sodium feldspar is albite $\left(\mathrm{Na}_{2} \mathrm{O}, \mathrm{Al}_{2} \mathrm{O}_{3}, 6 \mathrm{SiO}_{2}\right)$ and calcium feldspar is anorthite $\left(\mathrm{CaO}, \mathrm{Al}_{2} \mathrm{O}_{3}, 2 \mathrm{SiO}_{2}\right)$ and rock phosphate is a non-detrital sedimentary rock which contains high amounts of phosphate bearing minerals. The phosphate content of phosphorite is at least 15 to $20 \%$. Legumes respond well to rock phosphate which reflect on strong root systems, increased nodulation, good growth, report less fungal problems and increased crop production.( Aboel-Soud et al. 2003 and Mohamed 2004). However, Shafeek et al. (2004) found that chemical phosphate application increased dry weight of shoots, number of pods, number of seeds/pod, pod length and weight also seed yield as well as NPK content of cowpea and broad bean plants as compared to those obtained by rock phosphate. Moreover, Shafeek et al. (2005) studied the response of pea plant to different sources of phosphorus and potassium fertilizers (chemical and/or natural) added alone or mixture, found that characters of pea plant growth as expressed by length, average leaves and stem numbers, leaf area as well as the fresh and dry weight of stem, all of them had their peaks with addition mixture natural phosphorus (rock phosphate) and natural potassium (feldspar) fertilizers compared with either alone. They added also that all parameters of plant growth, total yield and yield components as well as the chemical composition of green pea seeds tissues recorded the highest significant values with applying the chemical sources of phosphorus and potassium fertilizers compared with the natural source alone.

Concerning to adding amino acids in the form of power mix compound which contain $21 \%$ amino acids, it is known that, amino acids as organic nitrogenous compounds stimulated cell growth acting as buffers maintaining favorable $\mathrm{pH}$ value within the plant cell as well as synthesizing other organic compounds, such as protein, amines, purines and pyrimidines, alkaloids, vitamins, enzymes, terpenoids and others (Goss, 1973).

Concerning ascobean compound which contain citric acid as well as ascorbic acid, it was found that, plant height, yield and its components as well as protein content in common bean, pea and faba bean were increased with application of citric acid ( AbdAllah et al.,2007) and Nour et al (2012) on snap bean. Spraying tomato plants with citric acid at 200 ppm increased vegetative growth, dry weight, yield and its components and NPK content as well as total protein (Ali et al., 2009).

Foliar nutrition is wildly used in a specific nutrient deficiency or to improve nutrients or under stress condition which increased plant height, number of leaves, plant fresh weight, dry seed yield and its components of many legumes as mentioned by several investigations, i.e. David et al. (1994), Helal et al. (2005), Kaya et al. (2005), El-Tohamy and El-Greadly (2007), Amen et al. (2007), Omaima Mohammed et al. (2009) and El-Bassiony et al. (2010) .

This work aimed to study the influence of using some natural fertilizers combined with some 
biofertilyzers as well as spraying pea plants with some organic stimulators on pea plants to improve its growth, increase pod yield and hasten its quality.

\section{Materials and Methods}

The present work was carried out during two successive winter seasons of 2011 and 2012 at the Experimental Farm of Kaha Station, Qalubia Governorate. Soil was clay in texture with $7.5 \mathrm{PH}$, 3.47 EC mmhos, $1.23 \%$ organic matters, $115 \mathrm{ppm} \mathrm{N}$, 52 ppm P and 103 ppm K. Seeds of pea cv. Master-B were obtained from Horticultural Research Institute, Agriculture Research Center, Egypt and sown on October 25th and 30th in 2011 and 2012, respectively. A split plot design system with three replicates was adopted. The plot area was $\left(8.4 \mathrm{~m}^{2}\right)$ and includes 3 ridges each of $(0.7 \mathrm{~m})$ width and $(4.0 \mathrm{~m})$ length. A guard row was left between each experimental unit to avoid drift spray. Eighteen treatments, i.e., the combination among six natural and biological materials were distributed in the main plots as the following:
1- Recommended mineral fertilization $40 \mathrm{~kg} \mathrm{~N}+30$ $\mathrm{kg} \mathrm{P}_{2} \mathrm{O}_{5}+48 \mathrm{~kg} \mathrm{~K}_{2} \mathrm{O} /$ fed (control)

2- Rock phosphate + feldespar + rhizobium

3- Rock phosphate + feldespar + rhizobium + mycorrhizal

4- Rock phosphate + feldespar + mycorrhizal

5- Rock phosphate + feldespar + rhizobium + potassiumag + phosphoren

6- Rhizobium + mycorrhizal

In addition,three compounds (ascobean, power- mix and water) were used as foliar nutrition which was arranged in the sub plots. Plants were sprayed three times with aqueous solution of the used materials, the first spray was conducted at the three true leaves stage, whereas the second and third spray were preformed 15 days intervals. Natural materials (rock phosphate and feldespar) were mixed with soil before sowing during soil preparation .While, the used biological materials, i.e., rhizobium, potassiumag, phosphoren and mycorrhizal were added at a rate of $3 \mathrm{~kg}$ per fedan as a suspension and the seeds were treated with it before sowing

Table 1. Names and its contains of the materials used in this study.

\begin{tabular}{ccc}
\hline Compounds name & Composition & Concentration
\end{tabular}

Foliar nutrition

1-Ascobean

2- Power -mix
Ascorbic acid and citric acid $38 \%$, Simulative organic matter $62 \%$
$1 \mathrm{~g} /$ liter water

Amino acids 21\%,Riboflavin 3\%, $1.5 \mathrm{~cm} /$ liter water cytokinines $0.3 \%$, gibberllic acid $0.001 \%$, potassium citrate $4.5 \%$

3-Water Distilled water

Natural materials

1- Rock phosphate

$\mathrm{P}_{2} \mathrm{O}_{5} 25, \mathrm{~K}_{2} \mathrm{O}$ 0.3, $\mathrm{SiO} 8.0, \mathrm{CaO} 41.2, \mathrm{Al}_{2} \mathrm{O}_{3}$

$120 \mathrm{~kg} / \mathrm{fed}$

$$
0.4 \%
$$

2-Feldespar

$\mathrm{K}_{2} \mathrm{O}$ 10.1, $\mathrm{P}_{2} \mathrm{O}_{5}$ 0.1, $\mathrm{SiO}$ 66.1, $\mathrm{CaO} 0.2$, $\mathrm{Al}_{2} \mathrm{O}_{3} 17.3 \%$

Biological materials

1-phosphoren

Phosphorus solubilising microorganisms(Bacillus megatherium var.phossphaticum)

2-Rhizobium

Rhizobium sp is a nitrogen fixing biofertilizer (Rhizobium leguminosarum)

$3 \mathrm{~kg} / \mathrm{fed}$

mixed with wilting seeds before sowing

3 -Potassiumag

Potassium solubilising micro-organisms

4- Mycorrhizal

Beneficial microorganisms called

Arbuscular mycorrhizal fungi.

The other agricultural practices were followed according to the recommendation for pea plantation without adding any chemical fertilizers. The following data were recorded:
I. Vegetative growth parameters:

Three plants were chosen randomly from every treatment in the three replicates at flowering stage in order to determine the following: 
-Plant length (the length of main stem $\mathrm{cm}$ ) -Leaves number/plant

-Fresh weight and dry weight (g/plant): A random sample of other three plants from each plant was taken and dried at $70 \mathrm{C}^{\mathrm{o}}$ till constant weight and the dry weight of whole plant was determined

\section{II- Pod yield and its characteristics.}

A random sample of 10 fresh pods (in green mature stage) from each plot was taken to determine the following data:

Pod length $(\mathrm{cm})$ - Pod diameter $(\mathrm{cm})$ - Number of seeds /pod -Average pod weight (g) - Weight of 100 seeds( $\mathrm{g})$ - Total pod yield (ton/fed)

\section{III- Chemical properties of pea seeds as well as chlorophyll leaf reading}

Total leaf chlorophyll reading was measured using Minolta chlorophyll meter SPAD- 501 as SPAD units

Total protein $\%$ : It was determined as nitrogen in dry seeds content and converted to its equivalent protein content by multiplying $\mathrm{N}$ content $\times 6.25$ (A.O.A.C.1975)

Total nitrogen, phosphorus and potassium were determined in dry seed on the basis of dry weight according to the methods described by Bremner and Mulvaney (1982), Olsen and Sommers(1982) and Jackson(1967),respectively.

Total sugars, it was determined calorimetrically on the basis of seed dry matter, using spectrophotometer with the phenol sulphuric acid method described by Dubois et al. (1956).

\section{Statistical analysis:}

Data obtained were subjected to the proper analysis of variance (split-plot design) as described by Snedecor and Cochran (1980) using M. stat program. Averages between treatments were differentiated by using LSD at 5\% level.

\section{Results and Discussion}

\section{Vegetative growth parameters:}

I.1 Effect of natural and biological fertilizers:

Data recorded in Table (2).showed that all studied plant growth parameters, i.e., plant length, number of leaves/plant, fresh and dry weight of foliage per plant were significantly increased by adding natural and biological materials to the soil before sowing pea seeds. In this respect, adding rock phosphate + feldespar + rhizobium + mycorrhizal was the best effective treatment on vegetative growth. This increase may be due to the influence of the natural elements of phosphorus and potassium in the rock phosphate as well as feldspar as rich sources for phosphate and potassium. These results are agreement with those obtained by Aboel-Soud et al. (2003), Mohamed (2004), Shafeek et al (2004) and Shafeek et al. (2005), studied the response of pea plant to different sources of phosphorus and potassium fertilizers (chemical and/or natural) when were alone or in mixture. The parameters of pea plant growth as expressed by plant length, average leaves number/plant as well as the fresh and dry weight, all of them had their peaks with addition mixture natural phosphorus ( rock phosphate ) and natural potassium (feldspar) fertilizers compared with either alone. mycorrhiza may especially enhance plant uptake of phosphors $(\mathrm{P})$, nitrogen (N) and micro nutrients (Marschner and Dell 1994, Ganie et al., 2010) worked on pea. Results of the present experiment clearly indicated that the co- inoculation of Rhizobium, Azotobacter and phosphorus solubilising microorganism (PSM) produced noticeably highest growth.

\section{I.2 Effect of foliar nutrition}

The results of foliar spray by the studied nutrition materials, i.e., power-mix and ascobean as affect on vegetative growth are presented in Table(2) .It is clear that spraying pea plants by power - mix caused a higher increase in plant growth parameters, i.e., plant length, number of leaves, fresh and dry weight of foliage per plant in both growing seasons. This increase is due to power mix which contain $21 \%$ amino acids .It is known that, amino acids as organic nitrogenous compounds stimulated cell growth acting as buffers maintaining favorable $\mathrm{pH}$ value within the plant cell as well as synthesizing other organic compounds, such as protein, vitamins, enzymes, and others (Goss, 1973). Foliar nutrition is wildly used in a specific nutrient deficiency or to improve nutrients which increased plant height, number of leaves, and plant fresh weight of many legumes; El-Tohamy and El-Greadly (2007), Omaima Mohamed et al. (2009), Kaya et al. (2005) and El-Bassiony et al. (2010). Also Helal et al. (2005) and Amen et al. (2007) came to similar results.

\section{I.3 Effect of the interaction between natural and biological fertilizer with foliar nutrition}

Data in Table (2) show the interaction effect of fertilizer, i.e. natural and biological materials and foliar nutrition on the vegetative growth; The results show that, adding rock phosphate + feldespar + rhizobium + mycorrhizal combined with spraying with power mix gave the highest values of no of leaves/plant and fresh weight. While, it gave insignificant increase compared with the other treatments in both growing seasons for plant length and dry weight. 
Table 2. Effect of natural and biological fertilization and foliar spray with ascobean, power mix and its interaction on the vegetative growth of pea plants during the two seasons of 2011 and 2012.

\begin{tabular}{|c|c|c|c|c|c|c|c|c|c|}
\hline \multirow{2}{*}{\multicolumn{2}{|c|}{ Treatments }} & \multirow{2}{*}{\multicolumn{2}{|c|}{$\begin{array}{c}\text { Plant length } \\
\mathrm{cm}\end{array}$}} & \multirow{2}{*}{\multicolumn{2}{|c|}{$\begin{array}{l}\text { No. of. leaves } \\
\text { / plant }\end{array}$}} & \multicolumn{4}{|c|}{ Weight g/ plant } \\
\hline & & & & & & & esh & & \\
\hline Fertilization & $\begin{array}{c}\text { Foliar } \\
\text { nutrition }\end{array}$ & 2011 & 2012 & 2011 & 2012 & 2011 & 2012 & 2011 & 2012 \\
\hline \multirow{3}{*}{$\begin{array}{l}\text { T1 (Recommended } \\
\text { fertilization (control) }\end{array}$} & Ascobean & 43.02 & 39.56 & 17.67 & 16.16 & 19.68 & 18.43 & 5.60 & 4.21 \\
\hline & Power mix & 45.08 & 43.17 & 19.77 & 17.25 & 22.63 & 20.54 & 5.90 & 4.12 \\
\hline & water & 41.63 & 38.39 & 17.17 & 15.51 & 18.80 & 17.47 & 5.37 & 3.83 \\
\hline \multicolumn{2}{|c|}{ Means of fertilization } & 43.24 & 40.37 & 18.20 & 16.31 & 20.37 & 18.81 & 5.62 & 4.05 \\
\hline \multirow{3}{*}{$\begin{array}{l}\text { T2(Rock phosphate + } \\
\text { Feldespar + Rhizobium) }\end{array}$} & Ascobean & 43.93 & 41.27 & 18.67 & 17.28 & 22.60 & 19.88 & 5.55 & 3.94 \\
\hline & Power mix & 45.25 & 42.50 & 19.17 & 19.22 & 23.47 & 21.70 & 5.70 & 3.93 \\
\hline & water & 43.50 & 40.22 & 18.16 & 16.50 & 21.62 & 16.99 & 5.63 & 3.78 \\
\hline \multicolumn{2}{|c|}{ Means of fertilization } & 44.22 & 41.33 & 18.66 & 17.67 & 22.56 & 19.52 & 5.63 & 3.88 \\
\hline \multirow{3}{*}{ T3 } & Ascobean & 45.77 & 44.22 & 23.77 & 19.86 & 24.30 & 21.57 & 5.85 & 4.24 \\
\hline & Power mix & 46.46 & 46.78 & 25.56 & 22.11 & 24.68 & 23.11 & 5.90 & 4.30 \\
\hline & water & 41.77 & 40.11 & 20.43 & 16.83 & 21.24 & 21.63 & 5.50 & 3.95 \\
\hline \multicolumn{2}{|c|}{ Means of fertilization } & 44.66 & 43.70 & 23.25 & 19.60 & 23.41 & 22.10 & 5.75 & 4.16 \\
\hline T4(Rock phosphate + & Ascobean & 45.97 & 43.00 & 12.55 & 11.91 & 19.85 & 18.55 & 4.30 & 2.99 \\
\hline \multirow{2}{*}{ Feldespar + Mycorrhizal) } & Power mix & 46.77 & 44.15 & 17.00 & 15.14 & 21.48 & 21.31 & 5.35 & 4.08 \\
\hline & water & 46.25 & 40.28 & 22.00 & 16.75 & 19.34 & 15.34 & 4.50 & 3.91 \\
\hline \multicolumn{2}{|c|}{ Means of fertilization } & 46.32 & 42.47 & 17.18 & 14.60 & 20.22 & 18.40 & 4.72 & 3.66 \\
\hline \multirow{3}{*}{$\begin{array}{l}\text { T5 }(\mathrm{T} 2+\text { Potassiumag }+ \\
\text { phosphoren })\end{array}$} & Ascobean & 44.98 & 44.00 & 20.67 & 19.08 & 22.75 & 21.27 & 5.30 & 4.00 \\
\hline & Power mix & 46.17 & 44.84 & 24.80 & 21.99 & 25.03 & 24.53 & 5.74 & 4.43 \\
\hline & water & 43.90 & 41.44 & 18.07 & 15.59 & 21.87 & 20.20 & 5.07 & 3.85 \\
\hline \multicolumn{2}{|c|}{ Means of fertilization } & 45.01 & 43.42 & 21.17 & 18.89 & 23.21 & 22.00 & 5.37 & 4.10 \\
\hline \multirow{3}{*}{$\begin{array}{l}\text { T6( Rhizobium + } \\
\text { Mycorrhizal) }\end{array}$} & Ascobean & 42.72 & 44.71 & 18.77 & 13.30 & 17.40 & 17.68 & 4.63 & 4.21 \\
\hline & Power mix & 42.50 & 42.50 & 19.27 & 13.75 & 17.05 & 16.29 & 4.55 & 4.17 \\
\hline & water & 40.50 & 40.25 & 17.00 & 12.33 & 14.45 & 13.39 & 4.31 & 4.05 \\
\hline \multicolumn{2}{|c|}{ Means of fertilization } & 41.90 & 42.48 & 18.34 & 13.13 & 16.30 & 15.79 & 4.49 & 4.14 \\
\hline \multirow{3}{*}{ Means of foliar nutrition } & Ascobean & 44.39 & 42.79 & 18.68 & 16.27 & 21.09 & 19.56 & 5.21 & 3.93 \\
\hline & Power mix & 45.37 & 43.98 & 20.92 & 18.24 & 22.39 & 21.25 & 5.52 & 4.17 \\
\hline & water & 42.92 & 40.11 & 18.80 & 15.59 & 19.55 & 17.50 & 5.06 & 3.89 \\
\hline \multirow{3}{*}{$\begin{array}{l}\text { L.S.D } \\
\text { at } 5 \%\end{array}$} & Fertilization & 1.50 & 1.63 & 1.90 & 2.78 & 1.38 & 0.49 & 0.59 & 0.02 \\
\hline & $\begin{array}{l}\text { Foliar } \\
\text { nutrition }\end{array}$ & N.S & 2.76 & 1.59 & 1.17 & 0.97 & 0.32 & N.S & 0.01 \\
\hline & Interaction & N.S & N.S & 1.46 & 0.98 & N.S & 0.27 & N.S & N.S \\
\hline
\end{tabular}

\section{II- Pod yield and its characteristics.}

\section{II.1 Effect of natural and biological fertilizers:}

Data in Table $(3,4)$ show the effect of natural materials (rock phosphate and feldespar) and biological fertilizers (rhizobium, potassiumag , phosphoren and mycorrhizal) on green pod yield and its characters. Data indicate that adding rock phosphate + feldespar + rhizobium + mycorrhizal or rock phosphate + feldespar + rhizobium + potassiumag + phosphoren, respectively had a favorable significant effect on 100 green seed weight, number of green seeds per pod and green pod weight. These results are in good line with those obtained from the data of vegetative growth in Table (2) in this study. In this regard, Rabbani et al. (2005), Jonah et al (2012) and (Carter et al., 1994) reported that rizobium inoculation improved yield and its quality of leguminous vegetable crops. Mahdi et al. (2011) reported that use of phosphate solubilizing microorganisms play vital role in solubilizing the insoluble forms of phosphorus and increases crop yield. Moreover, Legumes responded well to rock phosphate and this reflect in producing strong root systems, increasing nodulation, vigor growth, less fungal infection problems and consequently increased crop production,( AboelSoud et al. 2003 and Mohamed, 2004). While, natural and biological materials did not exert any considerable effects on green pod length, green pod diameter and total green pod yield in both growth seasons.

\section{II.2 Effect of foliar nutrition}

Data recorded in Table $(3,4)$ showed that all studied parameters of yield and its components, i.e., green pod diameter, number of green seeds per pod , 100 green seed weight, green pod weight and total green pod yield in both growth seasons were increased by spraying plants with power mix and 
ascobean treatments, respectively. While, green pod length gave the highest values using ascobean treatment in two seasons. This increase is due to the stimulation effect of power mix which contains $21 \%$ amino acids. Concerning the significant role of ascobean compound which contain $38 \%$ of ascorbic acid and citric acid and $62 \%$ simulative organic matter as shown in Table(1). Yield and its components in common bean, pea and faba bean were increased with application of citric acid as mentioned by ( Abd- Allah et al.,2007 and Nour et al ,2012) on snap bean. Spraying tomato plants with citric acid at $200 \mathrm{ppm}$ increased yield and its components (Ali et al., 2009). Foliar nutrition is wildly used in a specific nutrient deficiency or to improve nutrients which increased yield and its components of many legumes David et al. (1994), Kaya et al. (2005), El-Tohamy and El-Greadly (2007), Omaima Mohammed et al. (2009) and ElBassiony et al. (2010) .

\section{II.3 Effect of the interaction between natural and} biological fertilizer with foliar nutrition

As for the combined effect of both fertilizer with natural materials (rock phosphate and feldespar) and biological fertilizers (rhizobium, potassiumag , phosphoren and mycorrhizal) and foliar spray with (power-mix and ascobean), data in Table $(3,4)$ indicate that non significant effects were obtained between values of yield and its components in both growing seasons, whereas the increment did not reach to $5 \%$ level of significance.

Table 3. Effect of natural and biological fertilization and foliar spray with ascobean, power mix and its interaction on pod length, pod diameter and no .of. seeds / pod of pea plants during the two seasons of 2011 and2012.

\begin{tabular}{|c|c|c|c|c|c|c|c|}
\hline \multirow{2}{*}{$\begin{array}{l}\text { Treatments } \\
\text { Fertilization }\end{array}$} & \multirow[b]{2}{*}{$\begin{array}{c}\text { Foliar } \\
\text { nutrition }\end{array}$} & \multicolumn{2}{|c|}{$\begin{array}{l}\text { Pod length } \\
\mathrm{cm}\end{array}$} & \multicolumn{2}{|c|}{$\begin{array}{c}\text { Pod diameter } \\
\mathrm{cm}\end{array}$} & \multicolumn{2}{|c|}{ No .of. seeds / pod } \\
\hline & & 2011 & 2012 & 2011 & 2012 & 2011 & 2012 \\
\hline \multirow{3}{*}{$\begin{array}{l}\text { Recommended } \\
\text { (control) }\end{array}$} & Ascobean & 10.10 & 10.10 & 1.28 & 1.16 & 8.07 & 8.40 \\
\hline & Power mix & 10.05 & 9.90 & 1.30 & 1.17 & 8.67 & 8.47 \\
\hline & water & 9.25 & 9.62 & 1.30 & 1.16 & 8.00 & 8.25 \\
\hline \multirow{4}{*}{$\begin{array}{l}\text { Means of fertilization } \\
\text { Rock phosphate }+ \text { Feldespar }+ \\
\text { Rhizobium) }\end{array}$} & & 9.80 & 9.87 & 1.29 & 1.16 & 8.24 & 8.37 \\
\hline & Ascobean & 9.63 & 10.02 & 1.27 & 1.12 & 8.37 & 8.67 \\
\hline & Power mix & 9.98 & 10.02 & 1.27 & 1.14 & 8.47 & 8.50 \\
\hline & water & 9.42 & 9.33 & 1.20 & 1.10 & 7.97 & 8.20 \\
\hline \multirow{4}{*}{$\begin{array}{l}\text { Means of fertilization } \\
\text { Rock phosphate }+ \text { Feldespar }+ \\
\text { Rhizobium }+ \text { Mycorrhizal }\end{array}$} & & 9.68 & 9.78 & 1.24 & 1.12 & 8.26 & 8.46 \\
\hline & Ascobean & 9.45 & 9.90 & 1.27 & 1.20 & 8.97 & 9.23 \\
\hline & Power mix & 9.86 & 10.23 & 1.27 & 1.20 & 8.76 & 9.03 \\
\hline & water & 9.25 & 9.20 & 1.27 & 1.15 & 8.00 & 8.50 \\
\hline & 9.52 & 9.78 & 1.26 & 1.18 & 8.57 & 8.92 \\
\hline \multirow{3}{*}{$\begin{array}{l}\text { Rock phosphate }+ \text { Feldespar }+ \\
\text { Mycorrhizal }\end{array}$} & Ascobean & 10.13 & 10.15 & 1.27 & 1.19 & 8.67 & 8.67 \\
\hline & Power mix & 10.16 & 10.36 & 1.27 & 1.21 & 8.57 & 8.80 \\
\hline & water & 9.53 & 9.97 & 1.20 & 1.20 & 7.50 & 8.30 \\
\hline \multicolumn{2}{|l|}{ Means of fertilization } & 9.94 & 10.16 & 1.24 & 1.19 & 8.24 & 8.59 \\
\hline \multirow{3}{*}{$\begin{array}{l}\text { Rock phosphate }+ \text { Feldespar }+ \\
\text { Rhizobium }+ \text { Potassiumag }+ \\
\text { phosphoren) }\end{array}$} & Ascobean & 10.32 & 10.52 & 1.27 & 1.16 & 8.75 & 8.80 \\
\hline & Power mix & 9.55 & 9.60 & 1.27 & 1.17 & 8.63 & 8.90 \\
\hline & water & 9.34 & 9.38 & 1.25 & 1.12 & 8.00 & 8.33 \\
\hline \multicolumn{2}{|l|}{ Means of fertilization } & 9.74 & 9.83 & 1.24 & 1.15 & 8.46 & 8.68 \\
\hline \multirow[t]{3}{*}{ Rhizobium + Mycorrhizal } & Ascobean & 10.42 & 10.35 & 1.24 & 1.19 & 8.60 & 8.55 \\
\hline & Power mix & 9.85 & 9.91 & 1.24 & 1.23 & 8.57 & 8.53 \\
\hline & water & 10.00 & 10.16 & 1.22 & 1.18 & 8.40 & 8.30 \\
\hline \multicolumn{2}{|l|}{ Means of fertilization } & 10.09 & 10.14 & 1.23 & 1.20 & 8.52 & 8.46 \\
\hline \multirow{3}{*}{ Means of foliar nutrition } & Ascobean & 10.01 & 10.17 & 1.26 & 1.17 & 8.57 & 8.72 \\
\hline & Power mix & 9.91 & 10.00 & 1.27 & 1.19 & 8.61 & 8.71 \\
\hline & water & 9.46 & 9.61 & 1.24 & 1.15 & 7.98 & 8.32 \\
\hline \multirow{3}{*}{$\begin{array}{l}\text { L.S.D } \\
\text { at } 5 \%\end{array}$} & Fertilization & N.S & N.S & N.S & N.S & 0.47 & 0.68 \\
\hline & $\begin{array}{c}\text { Foliar } \\
\text { nutrition }\end{array}$ & 0.42 & 0.18 & N.S & 0.02 & 0.26 & 0.18 \\
\hline & Interaction & N.S & 0.15 & N.S & N.S & N.S & N.S \\
\hline
\end{tabular}


Table 4. Effect of natural and biological fertilization and foliar spray with ascobean, power mix and its interaction on weight of 100 seed, pod weight and green pod yield of pea plants during the two seasons of 2011 and 2012.

\begin{tabular}{|c|c|c|c|c|c|c|c|}
\hline \multicolumn{2}{|l|}{ Treatments } & \multicolumn{2}{|c|}{$\begin{array}{l}\text { Weight of } 100 \text { seeds } \\
\mathrm{g}\end{array}$} & \multicolumn{2}{|c|}{$\begin{array}{l}\text { Average pod } \\
\text { weight } \\
\text { g }\end{array}$} & \multicolumn{2}{|c|}{$\begin{array}{l}\text { Green pods yield } \\
\text { ton/fed }\end{array}$} \\
\hline Fertilization & $\begin{array}{c}\text { Foliar } \\
\text { nutrition }\end{array}$ & 2011 & 2012 & 2011 & 2012 & 2011 & 2012 \\
\hline \multirow{3}{*}{$\begin{array}{l}\text { Recommended } \\
\text { (control) }\end{array}$} & Ascobean & 34.47 & 35.30 & 6.65 & 6.43 & 4.23 & 4.17 \\
\hline & Power mix & 35.10 & 35.87 & 6.85 & 6.94 & 4.31 & 4.18 \\
\hline & water & 33.40 & 33.33 & 6.37 & 6.42 & 3.97 & 3.85 \\
\hline \multirow{4}{*}{$\begin{array}{l}\text { Means of fertilization } \\
\text { Rock phosphate }+ \text { Feldespar }+ \\
\text { Rhizobium) }\end{array}$} & & 34.32 & 34.83 & 6.62 & 6.59 & 4.17 & 4.07 \\
\hline & Ascobean & 35.90 & 34.60 & 6.63 & 6.97 & 4.30 & 4.49 \\
\hline & Power mix & 35.47 & 35.53 & 6.66 & 6.77 & 4.65 & 4.66 \\
\hline & water & 34.75 & 33.95 & 6.60 & 6.40 & 3.97 & 4.02 \\
\hline \multirow{4}{*}{$\begin{array}{l}\text { Means of fertilization } \\
\text { Rock phosphate }+ \text { Feldespar }+ \\
\text { Rhizobium }+ \text { Mycorrhizal }\end{array}$} & & 35.37 & 34.69 & 6.63 & 6.71 & 4.31 & 4.39 \\
\hline & Ascobean & 37.30 & 37.00 & 6.86 & 7.10 & 4.61 & 4.89 \\
\hline & Power mix & 37.15 & 36.17 & 7.10 & 7.33 & 4.71 & 4.98 \\
\hline & water & 35.10 & 34.25 & 6.33 & 6.57 & 4.03 & 4.43 \\
\hline \multirow{4}{*}{$\begin{array}{l}\text { Means of fertilization } \\
\text { Rock phosphate }+ \text { Feldespar }+ \\
\text { Mycorrhizal }\end{array}$} & & 36.52 & 35.80 & 6.77 & 6.99 & 4.45 & 4.77 \\
\hline & Ascobean & 34.75 & 34.27 & 6.60 & 6.55 & 4.58 & 4.38 \\
\hline & Power mix & 35.05 & 35.67 & 6.65 & 6.95 & 4.69 & 4.58 \\
\hline & water & 34.50 & 34.80 & 6.20 & 6.40 & 4.12 & 3.98 \\
\hline \multicolumn{2}{|l|}{ Means of fertilization } & 34.77 & 34.91 & 6.48 & 6.63 & 4.49 & 4.32 \\
\hline \multirow{4}{*}{$\begin{array}{l}\text { Rock phosphate }+ \text { Feldespar }+ \\
\text { Rhizobium }+ \text { Potassiumag }+ \\
\text { phosphoren) } \\
\text { Means of fertilization }\end{array}$} & Ascobean & 36.93 & 36.17 & 6.80 & 6.85 & 4.40 & 4.28 \\
\hline & Power mix & 36.10 & 36.07 & 6.90 & 7.15 & 4.76 & 4.66 \\
\hline & water & 33.47 & 32.60 & 6.35 & 6.55 & 4.06 & 4.00 \\
\hline & & 35.50 & 34.94 & 6.68 & 6.85 & 4.41 & 4.32 \\
\hline \multirow[t]{3}{*}{ Rhizobium + Mycorrhizal } & Ascobean & 34.13 & 34.20 & 6.63 & 6.63 & 4.17 & 4.35 \\
\hline & Power mix & 34.00 & 34.83 & 6.90 & 6.70 & 4.30 & 4.38 \\
\hline & water & 33.43 & 33.70 & 6.50 & 6.50 & 3.99 & 4.04 \\
\hline \multicolumn{2}{|l|}{ Means of fertilization } & 33.86 & 34.24 & 6.68 & 6.61 & 4.16 & 4.25 \\
\hline \multirow{3}{*}{ Means of foliar nutrition } & Ascobean & 35.58 & 35.26 & 6.69 & 6.76 & 4.38 & 4.43 \\
\hline & Power mix & 35.47 & 35.69 & 6.84 & 6.97 & 4.57 & 4.57 \\
\hline & water & 34.11 & 33.77 & 6.39 & 6.47 & 4.03 & 4.06 \\
\hline \multirow{3}{*}{$\begin{array}{l}\text { L.S.D } \\
\text { at } 5 \%\end{array}$} & Fertilization & N.S & 1.53 & N.S & 0.47 & N.S & N.S \\
\hline & $\begin{array}{c}\text { Foliar } \\
\text { nutrition }\end{array}$ & N.S & 1.56 & 0.31 & N.S & N.S & N.S \\
\hline & Interaction & N.S & N.S & N.S & N.S & N.S & N.S \\
\hline
\end{tabular}

\section{III-Chemical properties of pea seeds and leaf chlorophyll reading:}

\section{III.1 Effect of natural and biological fertilizer:}

Some significant effects of natural and biological materials on chemical properties, i.e. total sugar, protein percentage, $\mathrm{N}, \mathrm{P}, \mathrm{K}$ in pea seeds and leaf chlorophyll were obtained in Tables $(5,6)$. Data indicate that adding rock phosphate + feldespar + rhizobium + mycorrhizal had a favorable significant effect on $\mathrm{N} \%$ and protein percentage in pea seeds during the second season.

Concerning total sugar $\%$ in pea seeds it is evident that the most favorable treatment was rhizobium + mycorrhizal in both growing seasons. While, rock phosphate + feldespar + mycorrhizal and rock phosphate + feldespar + rhizobium were the best treatments for $\mathrm{P} \%$ in pea seeds and total chlorophyll in pea leaves, respectively. However, the results indicate that nonsignificant effect was obtained on the values of $\mathrm{K} \%$ in pea seeds in both growing seasons. These results are in agreement with those obtained by Rabbani et al. (2005) and Jonah et al. (2012) they reported that rizobium inoculation improved chemical composition of leguminous vegetable crops. Also, mycorrhiza may especially enhance plant uptake of phosphors $(\mathrm{P})$, nitrogen $(\mathrm{N})$ and micro nutrients. In this respect (Marschner and Dell 1994) and (Cmeron 2010). Geneva et al (2006) studied the response of pea (Pisum sativum $\mathrm{cv}$. Avola) to a rbuscular mycorrhizal fungi and demonstrated that the dual inoculation of pea plants significantly increased the photosynthetic rate and n i t r o g e f i x a t i o n a t i vity.

\section{III.2 Effect of foliar nutrition}

The results of foliar spray by the studied nutrition materials, i.e. power-mix and ascobean as affected on 
chemical properties of pea seeds as well as chlorophyll leaf content are presented in Tables $(5,6)$ .Data indicate that spraying pea plants by ascobean caused a higher increase in $\mathrm{N} \%, \mathrm{P} \%$ as well as protein percentage in pea dry seeds and leaf total chlorophyll in both growing seasons. Concerning total sugar $\%$ the best treatment was power- mix in the second season. However, the results indicate non significant effects were obtained on the values of seed content from $\mathrm{k} \%$ in both growing seasons. Ascobean compound contain citric acid as shown in Table (1). It was found that protein content in common bean, pea and faba bean were increased with application of citric acid as mentioned by ( Abd- Allah et al.,2007) and Nour et al (2012) on snap bean. It found also that, spraying tomato plants with citric acid at $200 \mathrm{ppm}$ increased NPK content as well as total protein (Ali et al., 2009).

\section{III.3 Effect of the interaction between natural and biological fertilizer with foliar nutrition}

The interaction results between the factors studied tabulated in Table $(5,6)$ show that adding rock phosphate + feldespar + rhizobium+ mycorrhizal and spray pea plants with ascobean gave the highest values of $\mathrm{N} \%$ and protein percentage. Concerning $\mathrm{P} \%$ the results indicated that adding rock phosphate + feldespar + mycorrhizal and spray pea plants with ascobean was the best treatment. Concerning total sugar \% it was found that the most favorable treatment was rhizobium + mycorrhizal and spray pea plants with ascobean .However, the interaction results indicated no significant effects on the values of leaf total chlorophyll and $\mathrm{k} \%$ in both growing seasons.

Table 5. Effect of natural and biological fertilization and foliar spray with ascobean, power mix and its interaction on total sugar, protein and leaf chlorophyll of pea plants during the two seasons of 2011 and 2012.

\begin{tabular}{|c|c|c|c|c|c|c|c|}
\hline \multirow{2}{*}{$\begin{array}{l}\text { Treatments } \\
\text { Fertilization }\end{array}$} & \multirow[b]{2}{*}{$\begin{array}{c}\text { Foliar } \\
\text { nutrition }\end{array}$} & \multicolumn{2}{|c|}{ Total sugar\% } & \multicolumn{2}{|c|}{ Protein \% } & \multicolumn{2}{|c|}{$\begin{array}{l}\text { Leaf chlorophyll } \\
\text { reading SPAD }\end{array}$} \\
\hline & & 2011 & 2012 & 2011 & 2012 & 2011 & 2012 \\
\hline \multirow{3}{*}{$\begin{array}{l}\text { Recommended } \\
\text { (control) }\end{array}$} & Ascobean & 18.12 & 18.60 & 18.77 & 17.20 & 50.36 & 41.10 \\
\hline & Power mix & 16.42 & 19.05 & 16.42 & 17.20 & 47.02 & 41.61 \\
\hline & water & 15.66 & 20.26 & 12.51 & 14.70 & 41.88 & 39.78 \\
\hline \multirow{4}{*}{$\begin{array}{l}\text { Means of fertilization } \\
\text { Rock phosphate }+ \text { Feldespar }+ \\
\text { Rhizobium) }\end{array}$} & & 16.73 & 19.30 & 15.90 & 16.37 & 46.42 & 40.83 \\
\hline & Ascobean & 16.09 & 18.39 & 19.72 & 21.89 & 47.70 & 43.93 \\
\hline & Power mix & 16.07 & 20.26 & 16.58 & 18.76 & 48.68 & 41.60 \\
\hline & water & 16.64 & 19.27 & 14.86 & 15.64 & 48.00 & 38.80 \\
\hline \multirow{4}{*}{$\begin{array}{l}\text { Means of fertilization } \\
\text { Rock phosphate }+ \text { Feldespar }+ \\
\text { Rhizobium }+ \text { Mycorrhizal }\end{array}$} & & 16.26 & 19.31 & 17.05 & 18.76 & 48.12 & 41.44 \\
\hline & Ascobean & 14.56 & 14.70 & 23.45 & 22.50 & 45.60 & 40.56 \\
\hline & Power mix & 14.51 & 14.34 & 18.14 & 19.39 & 42.00 & 41.76 \\
\hline & water & 16.39 & 20.26 & 15.33 & 18.76 & 40.50 & 39.23 \\
\hline \multirow{4}{*}{$\begin{array}{l}\text { Means of fertilization } \\
\text { Rock phosphate }+ \text { Feldespar }+ \\
\text { Mycorrhizal }\end{array}$} & & 15.16 & 16.43 & 18.97 & 20.22 & 42.70 & 40.52 \\
\hline & Ascobean & 17.92 & 17.96 & 21.59 & 21.58 & 48.45 & 45.66 \\
\hline & Power mix & 15.52 & 21.35 & 20.33 & 16.89 & 48.25 & 41.73 \\
\hline & water & 15.33 & 15.33 & 15.63 & 15.01 & 46.15 & 40.26 \\
\hline \multicolumn{2}{|l|}{ Means of fertilization } & 16.26 & 18.21 & 19.18 & 17.83 & 47.61 & 42.55 \\
\hline \multirow{3}{*}{$\begin{array}{l}\text { Rock phosphate }+ \text { Feldespar } \\
+ \text { Rhizobium }+ \text { Potassiumag }+ \\
\text { phosphoren) }\end{array}$} & Ascobean & 13.85 & 15.00 & 23.45 & 22.09 & 47.16 & 47.13 \\
\hline & Power mix & 16.15 & 20.26 & 17.52 & 18.14 & 43.60 & 40.93 \\
\hline & water & 14.64 & 16.35 & 15.64 & 15.64 & 47.53 & 41.56 \\
\hline Means of fertilization & & 14.88 & 17.20 & 18.86 & 18.62 & 46.10 & 39.87 \\
\hline \multirow[t]{3}{*}{ Rhizobium + Mycorrhizal } & Ascobean & 19.71 & 19.71 & 17.20 & 16.89 & 44.06 & 43.40 \\
\hline & Power mix & 20.06 & 19.49 & 20.33 & 20.33 & 46.16 & 44.95 \\
\hline & water & 20.12 & 19.71 & 15.64 & 15.32 & 38.66 & 43.05 \\
\hline \multicolumn{2}{|l|}{ Means of fertilization } & 19.96 & 19.63 & 17.72 & 17.51 & 42.96 & 43.80 \\
\hline \multirow{3}{*}{ Means of foliar nutrition } & Ascobean & 16.71 & 17.39 & 20.69 & 20.36 & 47.22 & 41.96 \\
\hline & Power mix & 16.46 & 19.12 & 18.22 & 18.45 & 45.95 & 42.10 \\
\hline & water & 16.46 & 18.53 & 14.93 & 15.84 & 43.78 & 40.45 \\
\hline \multirow{3}{*}{$\begin{array}{l}\text { L.S.D } \\
\text { at } 5 \%\end{array}$} & Fertilization & 0.86 & 0.84 & N.S & 2.12 & 2.25 & N.S \\
\hline & $\begin{array}{l}\text { Foliar } \\
\text { nutrition }\end{array}$ & N.S & 0.54 & 1.38 & 2.22 & 1.97 & N.S \\
\hline & Interaction & 0.37 & 0.45 & 1.16 & N.S & N.S & N.S \\
\hline
\end{tabular}


Table 6. Effect of natural and biological fertilization and foliar spray with ascobean, power mix and its interaction on N\%, P \% and K \% in pea seeds during the two seasons of 2011 and 2012.

\begin{tabular}{|c|c|c|c|c|c|c|c|c|}
\hline \multicolumn{3}{|l|}{ Treatments } & \multicolumn{2}{|c|}{$\mathrm{N} \%$} & \multicolumn{2}{|c|}{$\mathrm{P} \%$} & \multicolumn{2}{|c|}{$\mathrm{K} \%$} \\
\hline \multicolumn{2}{|l|}{ Fertilization } & $\begin{array}{c}\text { Foliar } \\
\text { nutrition }\end{array}$ & 2011 & 2012 & 2011 & 2012 & 2011 & 2012 \\
\hline \multirow{3}{*}{\multicolumn{2}{|c|}{ Recommended fertilization (control) }} & Ascobean & 3.00 & 2.75 & 0.87 & 0.78 & 2.99 & 2.87 \\
\hline & & Power mix & 2.63 & 2.75 & 0.89 & 0.79 & 2.10 & 3.22 \\
\hline & & water & 2.00 & 2.35 & 0.78 & 0.69 & 3.10 & 3.33 \\
\hline \multicolumn{3}{|l|}{ Means of fertilization } & 2.54 & 2.62 & 0.84 & 0.76 & 2.73 & 3.14 \\
\hline \multirow{3}{*}{$\begin{array}{l}\text { Rock phosphate }+ \text { Feldespar } \\
\text { Rhizobium) }\end{array}$} & + & Ascobean & 3.15 & 3.50 & 1.00 & 0.79 & 2.53 & 2.64 \\
\hline & & Power mix & 2.65 & 3.00 & 0.85 & 0.76 & 2.65 & 2.65 \\
\hline & & water & 2.00 & 2.50 & 0.87 & 0.79 & 2.87 & 3.56 \\
\hline \multicolumn{3}{|l|}{ Means of fertilization } & 2.60 & 3.00 & 0.91 & 0.78 & 2.68 & 2.95 \\
\hline Rock phosphate + Feldespar & & Ascobean & 3.75 & 3.60 & 0.96 & 0.82 & 2.99 & 3.45 \\
\hline \multirow{2}{*}{ Rhizobium+ Mycorrhizal } & & Power mix & 2.90 & 2.90 & 0.86 & 0.81 & 3.33 & 2.99 \\
\hline & & water & 2.45 & 3.00 & 0.84 & 0.77 & 3.22 & 3.10 \\
\hline \multicolumn{3}{|l|}{ Means of fertilization } & 3.04 & 3.17 & 0.88 & 0.79 & 3.18 & 3.18 \\
\hline \multirow{3}{*}{$\begin{array}{l}\text { Rock phosphate }+ \text { Feldespar } \\
\text { Mycorrhizal }\end{array}$} & & Ascobean & 3.45 & 3.14 & 0.88 & 0.81 & 2.99 & 2.87 \\
\hline & & Power mix & 3.25 & 2.70 & 0.87 & 0.79 & 2.64 & 3.22 \\
\hline & & water & 2.50 & 2.40 & 0.83 & 0.84 & 2.33 & 3.33 \\
\hline \multicolumn{3}{|l|}{ Means of fertilization } & 3.07 & 2.75 & 0.86 & 0.81 & 2.65 & 3.14 \\
\hline Rock phosphate + Feldespar & & Ascobean & 3.75 & 3.54 & 1.00 & 0.69 & 3.33 & 3.22 \\
\hline \multirow{2}{*}{\multicolumn{2}{|c|}{$\begin{array}{l}\text { Rhizobium+ } \\
\text { phosphoren) }\end{array}$}} & Power mix & 2.40 & 2.67 & 0.92 & 0.75 & 2.73 & 2.87 \\
\hline & & water & 2.50 & 2.50 & 0.84 & 0.69 & 3.10 & 2.99 \\
\hline \multicolumn{3}{|l|}{ Means of fertilization } & 2.89 & 2.90 & 0.92 & 0.71 & 3.05 & 3.03 \\
\hline \multirow{3}{*}{\multicolumn{2}{|c|}{ Rhizobium + Mycorrhizal }} & Ascobean & 2.75 & 2.70 & 0.73 & 0.72 & 2.76 & 2.99 \\
\hline & & Power mix & 2.80 & 3.25 & 0.79 & 0.80 & 3.10 & 2.99 \\
\hline & & water & 2.50 & 2.45 & 0.88 & 0.79 & 2.87 & 2.76 \\
\hline \multicolumn{3}{|l|}{ Means of fertilization } & 2.69 & 2.80 & 0.80 & 0.77 & 2.91 & 2.91 \\
\hline \multirow{3}{*}{\multicolumn{2}{|c|}{ Means of foliar nutrition }} & Ascobean & 3.31 & 3.20 & 0.90 & 0.77 & 2.93 & 3.01 \\
\hline & & Power mix & 2.77 & 2.88 & 0.86 & 0.78 & 2.76 & 2.99 \\
\hline & & water & 2.32 & 2.53 & 0.84 & 0.76 & 2.91 & 3.18 \\
\hline \multirow{3}{*}{\multicolumn{2}{|c|}{$\begin{array}{l}\text { L.S.D } \\
\text { at } 5 \%\end{array}$}} & Fertilization & N.S & 0.39 & N.S & 0.06 & N.S & N.S \\
\hline & & $\begin{array}{c}\text { Foliar } \\
\text { nutrition }\end{array}$ & 0.20 & 0.36 & 0.03 & N.S & N.S & N.S \\
\hline & & Interaction & 0.31 & N.S & 0.02 & 0.03 & N.S & N.S \\
\hline
\end{tabular}

\section{References}

Abd-Allah, E. M., M. A. Issa, S. M. Abd ElKader, H. S. Abd El-Salam and W.M. Abd El-Hakim .2007. Effect of some antioxidants treatments on yield,some chemical constituents and antinational factors of some vegetable legumes. 1st Intr. Conf. Desert Cultivation Problems and Solutions, Minia Univ., 27-29 March.

Aboel-Soud, A.A., A.A. Ragab, G.A.A. Mekhemar and F.T. Mikhaeel, 2003. Response of faba bean to inoculation with $\mathrm{N}$ fixers and phosphate dissolving bacteria as influenced by different sources of phosphorus. Egypt J. Applied Sci., 18: 73-90.

Ali, A. A., T. B. Ali and K. A. M. Nour. 2009. Antioxidants and some natural compounds applications in relation to tomato growth, yield and chemical constituents. Ann. Agric. Sci.Moshtohor, 47 (4): 469-477.
Amen,El-Sh.,A.H.Elmrsy and M.H.Tolba.2007. Effect of spraying with microelements and different fertilizer sources on pea yield and quality .J.Agric.Sci.Mansoura.Univ., 29(6)35313544

O. A. C. 1975. Association of official agricultural chemist's official methods of analysis of the A. O. A. C., Washington, D. C.

Bremner, J. M., and C. S. Mulvaney. 1982. Total nitrogen. In: Pag, A. L., R.H.Miller and D. R. Keeny(Eds).Methods of soil analysis. Part2, Amer.Soc .Agron.Madison, W.I.USA, 595-624

Cameron,D.D.2010.Arbuscular mycorrhizal fungi as ecosystem engineers .Plant Soil ,333:1-5.

Carter, J.M., W.K. Gardner and A.H. Gibson.1994. Improved growth and yield of faba beans (vicia faba cv fiord) by inoculation with strains of Rhizobium leguminosarum biovar. viciae in acid soils in south-west Victoria. Aust. J.Agric. Res. 94: 613-623. 
David, P.P, P.V. Nelson and D.C. Sanders, 1994. A humic acid improves growth of tomato seedling in solution culture. Plant Nutr. 17(1): 173-184.

Dubois,M.,A.Gilles,K.J.Hamihon,P.R.Rebers and P.A.Smith. 1956. A chlorimetric methods substances.Anal.Chem.28:350.

El-Bassiony, A. M., Z.F. Fawzy,M.M.H.Abd ElBaky and A.R. Mahmoud .2010. Response of snap bean plants to mineral fertilizers and humic acid application. J. Agric. Biol. Sci., 6(2):169175.

El-Tohamy, W. A. and N.H.M. El-Greadly. 2007. Physiological responses, growth, yield and quality of snap bean in response to foliar application of yeast, vitamin $\mathrm{E}$ and zinc under sandy soil conditions. Austr. J. Basic and Appl. Sci., 1(3):294-299.

Fitter, A.H.,

T.Helgason, A.Hodge.2011.Nutritional exchanges in the arbuscular mycorrhizal symbiosis implications for sustainable agriculture.Trends Cell Biol.25:68-72.

Ganie, N.A., R.B. SOLANKI and F. A. ALLIE.2010. Effect of bio-fertilizers on growth and yield of garden pea (Pisum sativum L.). Asian. J.Hort. 4 (2): 507-509.

Geneva,M, G. Zehirov, E. Djonova, N. Kaloyanova G. Georgiev and I. Stancheva.2006. The effect of inoculation of pea plants with mycorrhizal fungi and Rhizobium on nitrogen and phosphorus assimilation. Plant soil environs. 52 (10): 435440.

Goss, J. A. (1973). Amino acid synthesis and metabolism. In: New York. Physiology of Planta and their Cells. Pergamon Press, Inc., New York.

Helal,F.A.,S.A.El-Sayed and S.A.Saadon.2005. Use of some nutrient insecticide alternative to improve seeds yield and quality of soyabean and cowpea plant and their tetracychus cucurbitacearum .Egypt.J.Appl.Sci. 20(8b) 606613

Jackson,M.L.1967.Soil chemical analysis. PrenticHall,India,Private Limited,New Delhi.

Jonah,N.,G.N.Chemining,J.W.Muthomi and T.Solomon.2012.Effect of rizobium inoculation and nitrogen fertilizer application on growth, nodulation and yield of two garden pea genotypes.J.of Animal and Plant.Sci ,15(2) 2147-2156.
Kaya, M.,M. Atak, K.M.Khawar, Y.Cemalettin and S.Özcan 2005. Effect of pre- sowing seed treatment with zinc and foliar spray of humic acids on yield of common bean (Phaseolus vulgaris, L.). International J. Agric. Biol., 7(6):875-878.

Mahdi, S.S., G. I .Hassan, A. Hussain and F.Rasool.2011. Phosphorus Availability IssueIts Fixation and Role of Phosphate Solubilizing Bacteria in Phosphate Solubilization. Res. J. Agric. Scie., 2(1): 174-179.

Marschner, H., B.Dell.1994.Nutrient uptake in mycorrhizal symbiosis. Plant Soil, 159:89-102.

Mohamed, S.S., 2004. Integrated approach for rock phosphate sulfur combined with bio fertilization in sandy loam soil. Egypt J. Applied Sci., 19: 316-333.

Neeraj, G., S.S. Chatterjee, S.C. Sachin and C.Mahesh. 2009. Efficient nitrogen fixing rhizobial isolate infecting Vigna radiata .Asian. J. Agric. Scie. 1:62-65.

Nour, K. A. M., N. T. S.1 Mansour and G. S.A. Eisa.2012. Effect of some antioxidants on some physiological and anatomical characters of snap bean plants under sandy soil conditions . New York .Scie. J.5(5):1-8

Olsen, S. R. and L.E.Sommers .1982. Phosphorus . In:Page, A. L.; R. H. Miller and D. R. Keeney (Eds). Methods of soil analysis. Part 2 Amer. Soc. Agron. Madison, W. I. USA, 403-430

Omaima, O. Mohamed, H.M.Aricha, A.Bardisi and El-B.Rawia 2009. Effect of foliar spray with $\mathrm{Ca}, \mathrm{Mg}$ and vitamin $\mathrm{B} 1$ on the productivity and storability of snap bean grown in sandy soil. Zagazig J. Agric. Res., 36(1):41-62

Rabbani, M. G., A. R. M. Solaiman, K. M. Hossain and T. Hossain.2005. Effects of Rhizobium inoculant, nitrogen, phosphorus, and molybdenum on nodulation, yield and seed protein in pea.Korean. J. Crop Scie. 50: 112-119

Shafeek, M.R., F.S. Abdel-Al and A.H. Ali, 2004. The productivity of broad bean plant as affected by chemical and or natural phosphorus with different bio fertilizer. J. Agric. Sci. Mansoura Univ., 29: 2727-2740.

Shafeek, M.R., O.A.H. El-Zeiny and M.E. Ahmed. 2005. Effect of natural phosphate and potassium fertilizer on growth, yield and seed composition of pea plant in new reclaimed soil. Asian. J. Plant.Sci,4:608-612.

Snedercor, G. W. and W. G. Cochran .1980. Statistial Methoods, $7^{\text {th }}$ Ed., The Iowa state Univ., Press, Ames., Iowa, U. S. A. 


\title{
تأثير استخدام بعض المواد الطبيعية والأسمدة الحيوية على نمو وجودة محصول البسلة
}

\author{
يسرية أحمد ابراهيم بيان , ناهد محمد مهدى الثيمى

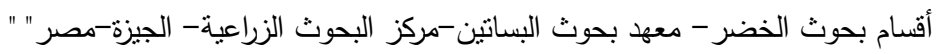

اجريت تجربتان حقلينان خلال الموسم الثنتوى لعامى 2012,2011 بمحطة التجارب بقها -محافظة القليوبية لدراسة تأثير التغذية الورقية ببعض

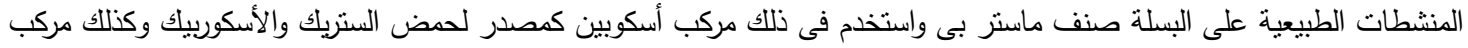
باوريكس كمصدر للأحملض الأمينية كما استخدم مركبى صخر الفوسفات الطبيعى كمصدر للفوسفور ومركب فيلسبار كمصدر للبوتاسيوم الطبيعى وذللك كإضافة أرضية قبل الزراعة -كما عوملت البذور قبل الزراعة ببعض المخصبات الحيوية وهى الفوسفورين كذذيب للفوسفور

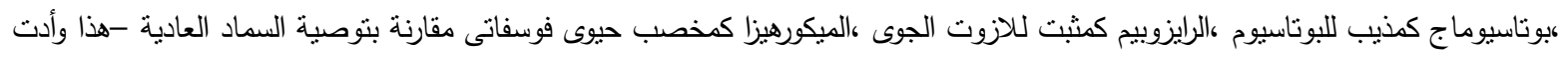

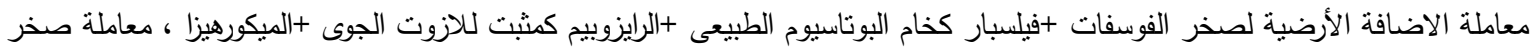

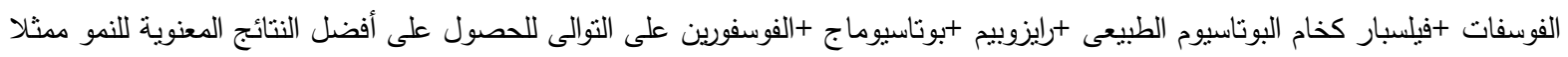

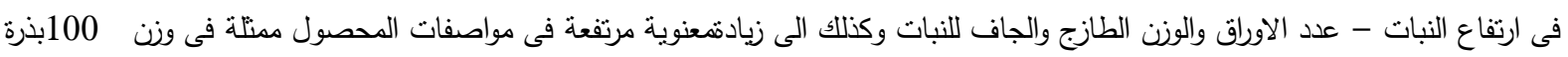

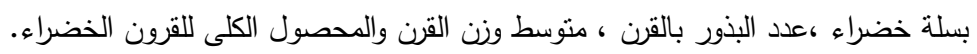

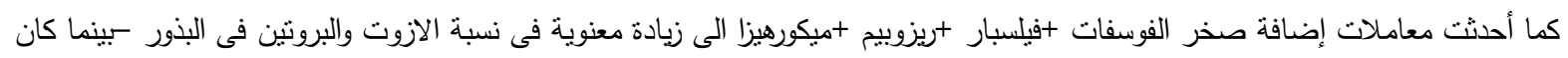

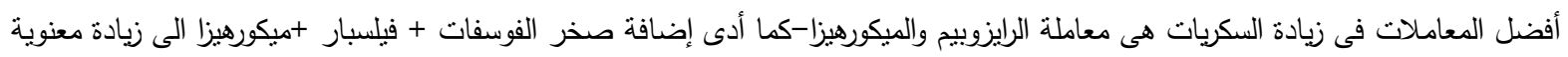
مرتفعة فى محتوى البذور من الفوسفور - كما أدى الرش بمركب الاسكوبين الى زيادة معنوية فى النيتروجين والفوسفور والبروتين ومحتوى الاوراق

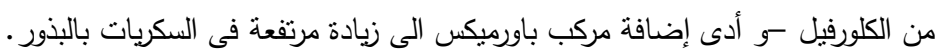

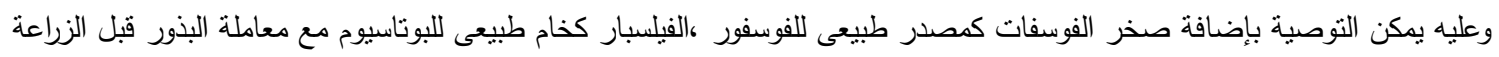

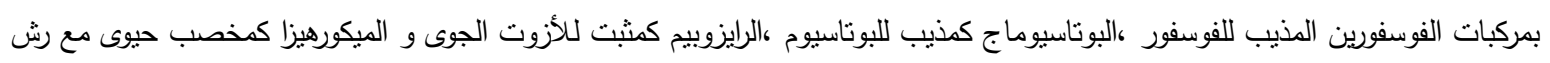

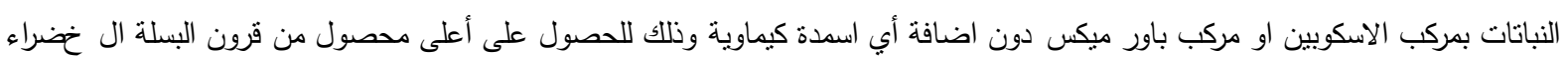
بمواصفات جيدة مقارنة بتوصية التسميد الكيماوى للبسلة. الكلمات الدالة :- بسلة - تغذية ورقية - أحماض أمينية - مخصبات حيوية - فيلسبار - صغر الفوسفات . 